
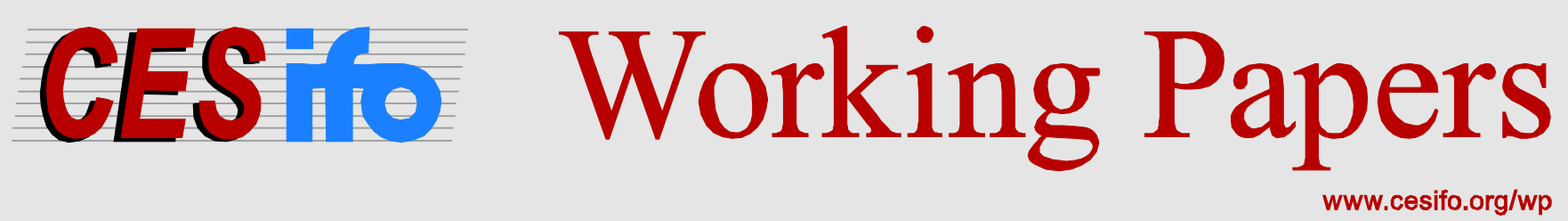

\title{
Money Can’t Buy EU Love: European Funds and the Brexit Referendum
}

\author{
Jan Fidrmuc \\ Martin Hulényi \\ Çiğdem Börke Tunalı
}

CESIFO WORKING PAPER NO. 6107

CATEgory 2: Public CHOICE

SEPTEMBER 2016
An electronic version of the paper may be downloaded
- from the SSRN website: Www.SSRN.com
- from the RePEc website: Www.RePEc.org
- from the CESifo website: www.CESifo-group.org/wp




\title{
Money Can’t Buy EU Love: European Funds and the Brexit Referendum
}

\begin{abstract}
We explore the role of the transfers that UK regions received from the European structural and cohesion funds, as well as other economic and social factors, in determining the support for the Remain vote in the Brexit referendum. We .nd that past European transfers have played virtually no role in the referendum. Economically strong regions tend to be in favor of remaining in the EU. Somewhat surprisingly, the intensity of immigration from the EU is positively correlated with the Remain vote.
\end{abstract}

JEL-Codes: D720, F020, F150.

Keywords: European integration, economic voting, cohesion policy.

Jan Fidrmuc*
Department of Economics and Finance
Brunel University
UK-Uxbridge, UB8 3PH
Jan.Fidrmuc@brunel.ac.uk

Martin Hulényi

Institute for Strategy and Analysis

Government Office of the Slovak Republic

martin.hulenyi@vlada.gov.sk
Çiğdem Börke Tunalı

Department of Economics

Faculty of Economics

Istanbul University / Turkey

cbtunali@istanbul.edu.tr

*corresponding author

September 21, 2016

The views expressed in this paper are those of the authors and do not necessarily represent the official position of the Government Office of the Slovak Republic. 


\section{Introduction}

On 23 June 2016, the United Kingdom held a referendum on continuing its European Union membership. Throughout the run up to the vote, the outcome was consistently predicted to be a close win for the Remain side. Yet, the actual outcome was a $52 \%$ support for Leave, putting the UK on the path towards becoming the first country ever to leave the EU.

The referendum campaign proved highly confrontational, with the emphasis of the debate focused on few contentious issues: the financial cost of EU membership, the burden of EU rules and regulations, and the labor-market impact of the free mobility of labor. The regional dimension was also important: England and Wales voted for leaving the EU while Scotland, Northern Ireland and Gibraltar supported staying in the EU.

One specific aspect of the UK-EU financial relations, the contributions that the less affluent UK regions receive because of the EU's Cohesion Policy (henceforth CP, also often referred to as structural and cohesion funds), has received very little exposure. While the UK is, overall, a net contributor to the EU budget, some of its regions receive non-negligible amounts of funds in this way. During the last three Programming Periods, 1994-99, 2000-06 and 2007-13, the UK received, on average, $€ 136$, $€ 131$ and $€ 52$ per person. ${ }^{1}$ The regional differences in the amounts received, however, are huge: during the 2007-13 period, the per-person payments ranged from $€ 1.2$ in Surrey and East and West Sussex to $€ 550$ per person in Cornwall and Isles of Scilly (Figure 1). The range was even wider in the past, the lowest/highest amounts for the 1994-99 and 2000-06 programming periods were $€ 0 / 562$ and $€ 34 / 1,484$, respectively (see Figures 2-3). ${ }^{2}$ Hence, some regions of the UK have benefited substantially, and were set to continue benefit, from CP payments to a considerable degree had the UK chosen to remain in the EU.

In this paper, we ask whether receiving funding from the $\mathrm{CP}$ played any role in the Brexit referendum. Specifically, we relate the percentage of voters in favor of remaining in the EU, at the NUTS2 level ${ }^{3}$, to the funds, on per-capita basis, received

\footnotetext{
${ }^{1}$ These figures pertain always to the entire programming period rather than being annual averages. The data used in this is calculation are discussed in greater detail in the data section.

${ }^{2}$ West Wales and the Valleys, Cornwall and the Isles of Scilly, and the Highlands and Islands received funding under the Convergence Objective (limited to regions with GDP per capita below $75 \%$ of the EU average). East Wales, Lowlands and Uplands of Scotland, Northern Ireland, Gibraltar, East England, East Midlands, London, Merseyside, North East England, North West England, South East England, South West England, South Yorkshire, West Midlands, and Yorkshire and Humberside are being funded under the Regional Competitiveness and Employment Objective, which given transitional support to regions that crossed the $75 \%$ threshold. See http://ec.europa.eu/regional_policy/how/coverage/index_en.cfm.

${ }^{3}$ NUTS (Nomenclature des unités territoriales statistiques) regions are geographicapical subdivisions used by EU countries and EU institutions for statistical reporting. There are three levels, NUTS1 (largest) to NUTS3 (smallest). Eligibility to receive CP transfers is determined at the level of NUTS2 regions.
} 
by the regions during the last three programming periods. We focus on NUTS2 regions as this is the level that the EU Cohesion Policy targets. ${ }^{4}$ Obviously, CP is not the only factor that could have affected support for EU membership. To account for some of the other factors that could have affected the Brexit vote, we also include the regions' GDP per capita, average hourly wage, employment rate, and the regions' exposure to immigration from the rest of the EU. Our results suggest that only the regions' economic performance is significantly related to the support for remaining in the EU: both GDP per capita and the average hourly wage are positively correlated with it. The CP transfers or exposure to immigration from the EU, in contrast, play little role.

This paper contributes to the growing literature on the benefits of European integration in general (Campos et al., 2014, 2015) and the Cohesion Policy in particular (Becker et al., 20100; Dall'Erba and Le Gallo, 2008), benefits from disintegration (Alesina and Spolaore, 2003; Fidrmuc, 2015) and determinants of support for European integration (de Vreese and Boomgaarden, 2005; Doyle and Fidrmuc, 2006; and Tillman, 2012). To the best of our knowledge, only one other paper, Arnorsson and Zoega (2016), has analyzed the voting in the Brexit referendum. They focus on the economic determinants of voting and attitudes and discuss also the response of the foreign-exchange markets to opinion polls in the run-up to the referendum and its immediate aftermath.

After outlining the data used in the next section, we present the results of our analysis in section 3, and offer some concluding remarks in section 4 .

\section{Data and Methodology}

To carry out our analysis, we combine information from a number of diverse sources. First, we use the regional Brexit referendum results, published by the Electoral Commission. ${ }^{5}$ These report detailed results (number of eligible voters, turnout, number of votes cast in favor of remaining and leaving, and others) for 382 electoral districts in the UK, including Gibraltar (we do not use the latter, as we lack economic data for it). Second, the CP allocations have been reported by the European Commission. ${ }^{6}$ The regional $\mathrm{CP}$ payments are only reported for the whole programming periods (1994-99, 2000-06 and 2007-13), not for individual years. Because of this, we use the total CP payments per person for each period. The remaining economic data are sourced from the European Regional Database compiled by Cambridge Economet-

\footnotetext{
${ }^{4}$ Specifically, regions can receive $\mathrm{CP}$ funding under three objectives. Objective 1 provides for fiscal transfers to regions whose output is below 75 percent of the EU average level. Objective 2 supports regions stricken by structural problems. Finally, Objective 3 targets those that require support for stimulating education, training and employment.

${ }^{5} \mathrm{See} \quad \mathrm{http} / /$ www.electoralcommission.org.uk/find-information-by-subject/elections-andreferendums/past-elections-and-referendums/eu-referendum/electorate-and-count-information.

${ }^{6}$ See http://ec.europa.eu/regional_policy/en/policy/evaluations/data-for-research/.
} 
rics. $^{7}$ We use the GDP per capita, average hourly wage, and the employment rate. Unlike with CP payments, these data are available annually: we use the figures for 2012, which is the latest years for which data are available. Finally, we observe migration from the UK Labor Force Survey (LFS) statistics. The Labor Force Survey is a quarterly nationally-representative survey, covering around 60 thousand households with 100 thousand respondents per quarter. It contains detailed information on the respondents' employment status and socio-economic characteristics, including their nationality. ${ }^{8}$ We use the information on nationality to compute the migrant share for each region and quarter. Since the main issue concerning migration has been the influx of migrants from the new member states that joined the EU in 2004, we compute the migrant share for all EU/EEA member countries (which we denote as $\mathrm{EU} 27)^{9}$, and separately for the ten new member states (EU10) that joined in $2004 .^{10}$ It is estimated that there are over 1 million of EU10 workers in the UK as of 2016, accounting for almost one-half of all EU workers. ${ }^{11}$ The large scale of EU10 immigration has had a profound effect on the UK society, culture and politics (though not on the labor market, see Tunali, Campos and Fidrmuc, 2016). To account for the relative size of the immigration shock, we compute the relative change in the size of the migrant stock between 2013 and 2003 (the latter being the last pre-accession year), for both groups of migrants (EU28 and EU10).

The data we used are not all at the same level of aggregation: the electoral data cover 381 districts (not including Gibraltar), the European Regional Database features 37 NUTS2 regions (in their 2006 definitions), and the LFS provides information on only 20 regions. We therefore aggregated the electoral districts up to the level of NUTS2 regions: we added up the numbers of valid votes and votes to remain and took their ratio to get the percentage of remain votes at the NUTS2 level. Since we could not disaggregate the larger regions used by the LFS, we assigned the migration change rates observed for LFS regions to all constituent NUTS2 regions.

Table 1 present the summary statistics for the variables used in the analysis (see also Figures 1 to 6 ). Note that the means are unweighted, which accounts for the slightly lower value of the average remain vote than the nation-wide figure of $48 \%$. The CP payments are in euros; we report both the aggregate figure for all three programming periods used in the analysis, as well as separate values for each period.

\footnotetext{
${ }^{7}$ See http://www.camecon.com/SubNational/SubNationalEurope/RegionalDatabase.aspx.

${ }^{8}$ See https://discover.ukdataservice.ac.uk/series/?sn=2000026.

${ }^{9}$ Specifically, we include the 14 old member states (not including the UK), the 10 countries that joined in 2004, as well as Iceland, Norway and Switzerland. We do not include Bulgaria and Romania, which joined the EU in 2007, as these two countries faced transitional restriction on free movement of workers within the EU until 2014. For the same reason, we do not include Croatia (EU member since 2013, currently still subject to transitional restrictions on labor mobility).

${ }^{10}$ The Czech Republic, Cyprus, Estonia, Hungary, Latvia, Lithuania, Malta, Poland, Slovakia, and Slovenia.

${ }^{11}$ See "EU migration: Eastern European workers in UK pass one million," http://www.bbc.co.uk/news/uk-37109747.
} 
GDP per capita and the average hourly wage are also in euros, which is the currency used in the original data. Output per person, average wage and employment rate all display substantial regional variations, as do CP payments (as already discussed in the Introduction). Finally, the change in the stock of EU immigrants is particularly noteworthy: while the stock of migrants from the EEA as a whole has increased by some $70 \%$, the immigration from the new member states has increased more than ninefold during the ten years immediately following accession! Again, we see substantial regional variation, from modest increases in Inner (and also Outer) London, to 34-fold increase in Northern Ireland.

The maps of CP payments, remain vote and immigration exposure in Figures 1 to 6 are especially interesting. The main beneficiaries of Cohesion Policy in the UK have been peripheral regions: Northern Ireland, parts of Scotland and Wales, and Cornwall. Of these, majorities Northern Ireland and especially Scotland support remaining in the EU, but Wales shows moderate majority in favor of leaving and Cornwall is rather strongly in favor of Brexit. The immigration experience also seems little correlated with the remain vote: London and South-Eastern England have experienced a relatively modest increase in immigration while Northern Ireland has been especially strongly affected (in relative terms) - yet both of these regions show a majority in favor of remaining in the EU.

The voting model that we estimate takes the following form:

$$
R_{i}=\beta_{0}+\beta_{1} C P_{i}+\beta_{2} Y_{i}+\beta_{3} W_{i}+\beta_{4} E_{i}+\beta_{5} M_{i}+\epsilon
$$

where $C P$ stands for cohesion policy payments per capita (either aggregated over all three programming periods or for one period), $Y, W$ and $E$ are the GDP per capita, average hourly wage and employment rate in 2012. Finally, $M$ is the ratio of migrant stock (from EU28 or EU10) in 2013 over the corresponding number in 2003. As the dependent variable is the share of votes per region (rather than an individual voting decision), we estimate all regressions using OLS. Note that besides the full model described by the above equation, we also estimate more parsimonious versions of the model. Finally, taking the logs of GDP, average wage and CP payments makes very little difference to the results; the results with logs are not reported but are available upon request.

\section{Results}

The results of our analysis are presented in Table 2 (univariate analysis) and Table 3 (multivariate analysis). In columns (1)-(4) of Table 2 , we relate the remain vote to the per-capita payments received by the UK regions in the last three programming periods, as well as to their sum over all three periods. Only the receipts for the 1994-99 period are marginally significant and positive. Hence, there is little evidence that regions that have benefited from Cohesion Policy funding tend to be more in 
favor of remaining in the EU. Recent receipts of CP funds, especially, have no bearing on the referendum outcome. The insignificant effect of CP transfers stands in sharp contrast to the economic performance of regions, reported in columns (5)-(7): both GDP per capita and the average hourly wage are strong predictors of the remain vote; the employment rate is also positive but insignificant. Finally, despite its strong prominence in pre-referendum debate, the relative impact of immigration - whether specifically from the new member states (column 8) or from all of the EEA28 (column 9) - has had no significant effect on the pro-EU vote.

The univariate regression results, however, can be misleading because the various factors considered can be correlated with each other, potentially causing omitted variable bias when not controlled for. Therefore, in Table 3, we consider all explanatory variables together. We do not include GDP per capita and average wage together, as these are closely correlated with each other and have similar effects. Likewise, we only include $\mathrm{CP}$ payments during the latest programming period and the aggregate payments, one at a time.

In columns (1) and (2), we relate the remain vote to CP payments during 200713, GDP per capita and employment rate in 2012, and the change in immigration from the EU10 and EU28, respectively. We also include a dummy variable for NUTS2 regions in England and Wales, the two countries of the UK with a majority for Brexit. The CP payments are not a significant predictor of the remain vote, as before. In fact, the only variables that are significant in columns (1) and (2) are GDP per capita (which is positively related to support for EU membership) and the England and Wales dummy (which suggests that after controlling for everything else, support for remaining in the EU is lower by some $15 \%$ in English and Welsh regions). Note that the change of immigration is not a significant predictor of the support for the EU, regardless of whether we consider only the EU10 countries or all of the EU28. Removing the England and Wales dummy has little effect on the coefficient for $\mathrm{CP}$ payments or those of the other variables, except that it results in migration appearing with a significantly positive coefficient (especially when considering immigration from the EU10).

Considering total payments over all three programming periods makes little difference, although the coefficient is marginally significant in column (6), in which the immigration change variable refers to EU28 countries. (including the England and Wales dummy again makes little difference, these results are not reported but are available upon request). Finally, when we omit both the England and Wales dummy and immigration change, the total $\mathrm{CP}$ receipts appear significant and positive. Given that this is the only regression in which CP appears as a significant factor, we believe not much importance should be ascribed to this result. The bulk of the results indeed suggest that past Cohesion policy payments have had little effect on the Brexit referendum. 


\section{Conclusions}

The EU Cohesion Policy has the potential to be a major tool for winning hearts and minds of European citizens. Accounting for around one third of the EU budget (second largest share after the Common Agricultural Policy), its aim is to foster the well-being and facilitate convergence of less developed regions in the EU. To this effect, the CP finances infrastructure projects, supports research and education and creates employment in the regions that qualify under one of its three objectives. In doing so, the EU acts as a modern Robin Hood, by collecting funds from the relatively rich regions to redistribute them to the relatively poor ones. By focusing on regions rather than countries, moreover, the EU ensures that virtually every member state benefits from this policy: even the net contributor countries, such as the UK, have regions that have received substantial transfers from Brussels. Unlike the Common Agricultural Policy, Cohesion Policy does not support inefficient producers or practices. These fact should help create constituencies in each country that benefit from, and support, European integration.

In this paper, we put this proposition to a test, using the regional distribution of pro-EU support in the recent Brexit referendum in the UK. Although the UK is a net contributor to the EU budget ${ }^{12}$, several of its regions have been on the receiving end of CP payments. In our analysis, however, we find little evidence that such regions display stronger pro-EU sentiment: the CP receipts, in per capita terms, are not correlated with the share of the vote to remain at the NUTS2 level (this is the level at which the CP payments are disbursed). Similarly, the exposure to immigration from the EU does not translate into lower remain vote. Instead, economic performance matters: both GDP per capita and the average hourly wage are strongly and positively correlated with the vote to remain. Arnorsson and Zoega (2016) reach similar findings in their analysis of the economic determinants of Brexit. ${ }^{13}$

The support for EU membership, therefore, is highest in the areas that have done well economically in recent years. These areas benefited from globalization and international flows of capital and also labor. The areas with majorities against the EU, in turn, are those that missed out on these benefits (see the discussion of economic insecurity as a driver of populism in Inglehard and Norris, 2016). The EU - and the UK government - can and should help such areas and this is indeed what the Cohesion Policy is designed to do, given its objectives. The fact that the regions receiving $\mathrm{CP}$ funds do not show greater support for EU membership suggests that the EU needs to reconsider both how it spends its regional aid and especially how it communicates the fruits of its policies to the EU public.

\footnotetext{
${ }^{12}$ The UK net contribution accounted for $0.25 \%$ of GPD during the 2007-13 programming period (see "EU expenditure and revenue 2007-2013". Europa. European Commission, http://ec.europa.eu/budget/figures/2007-2013/index_en.cfm). This puts the country in the ninth place in the EU, after Belgium, Germany, the Netherlands, Sweden, France, Luxembourg, and Italy.

${ }^{13}$ Arnorsson and Zoega do not consider the role of CP. On immigration, they likewise find no evidence that it is significantly related with support for leaving the EU.
} 


\section{References}

[1] Alesina, A., Spolaore, E. (2003). The Size of Nations. MIT Press, Cambridge, MA.

[2] Arnorsson, A., and G. Zoega (2016). "On the Causes of Brexit." CESIfo Working Paper No. 6056, CESIfo, Munich.

[3] Becker, S. O., Egger, P. H., and Von Ehrlich, M. (2010). "Going NUTS: The Effect of EU Structural Funds on Regional Performance." Journal of Public Economics 94(9):578-590.

[4] Campos, N. F., Coricelli, F., and Moretti, L. (2014). "Economic Growth and Political Integration: Estimating the Benefits from Membership in the European Union Using the Synthetic Counterfactuals Method." IZA DP No. 8162.

[5] Campos, N. F., Coricelli, F., and Moretti, L. (2015). "Norwegian Rhapsody? The Political Economy Benefits of Regional Integration." IZA DP No. 9098.

[6] Dall'Erba, S. and Le Gallo, J. (2008). "Regional Convergence and the Impact of European Structural Funds over 1989-1999: A Spatial Econometric Analysis*. Papers in Regional Science 87(2):219-244.

[7] de Vreese, C.H., Boomgaarden, H.G. (2005). "Projecting EU Referendums: Fear of Immigration and Support for European Integration." European Union Politics $6(1), 59-82$.

[8] Doyle, O., Fidrmuc, J. (2006). "Who Favors Enlargement? Determinants of Support for EU Membership in the Candidate Countries' Referenda." European Journal of Political Economy 22, 520-543.

[9] Inglehard, R.F., and P. Norris (2016). "Trump, Brexit, and the Rise of Populism: Economic Have-Nots and Cultural Backlash." RWP16-026, John F. Kennedy School of Government, Harvard University.

[10] Fidrmuc, J. (2015). "Political Economy of Transfer Unions," European Journal of Political Economy 40:147-157.

[11] Tillman, E.R. (2012). "Support for the euro, political knowledge, and voting behavior in the 2001 and 2005 UK general elections." European Union Politics, $13(3), 367-389$.

[12] Tunalı, Ç.B., J. Fidrmuc and N. Campos (2016). "Flocking Eastern Europeans: Causality Analysis of EU Immigration to the UK." Brunel University, mimeo. 


\begin{tabular}{l|rrrrr}
\hline \hline \multicolumn{1}{l|}{ Table 1 Summary Statistics } & Obs & Mean & St.dev. & Min & Max \\
Vote Remain [\%] & 37 & 47.1 & 8.1 & 34.8 & 71.9 \\
CP Payments 07-13 [€] & 37 & 68.6 & 110.1 & 1.2 & 549.6 \\
CP Payments 00-06 [€] & 37 & 152.6 & 169.1 & 0.0 & 561.9 \\
CP Payments 94-99 [€] & 37 & 188.8 & 290.6 & 32.1 & 1484.3 \\
CP Payments 94-13 [€] & 37 & 410.0 & 444.5 & 33.8 & 1561.6 \\
GDP pc 2012 [€] & 37 & 30,093 & 12,251 & 20,163 & 94,621 \\
Avg hourly wage 2012 [€] & 37 & 20.5 & 6.4 & 15.8 & 54.4 \\
Emplyment rate 2012 [\&] & 37 & 46.7 & 3.0 & 39.4 & 53.6 \\
EU10 migrant stock ratio 2013/03 & 37 & 9.3 & 6.1 & 1.7 & 34.2 \\
EU27 migrant stock ratio 2013/03 & 37 & 1.7 & 0.5 & 0.9 & 3.0 \\
\hline \hline
\end{tabular}

\begin{tabular}{|c|c|c|c|c|c|c|c|c|c|}
\hline & (1) & (2) & (3) & (4) & (5) & (6) & (7) & (8) & (9) \\
\hline CP Payments 07-13 [€] & $\begin{array}{l}-0.001 \\
(0.012)\end{array}$ & & & & & & & & \\
\hline CP Payments 00-06 $[€]$ & & $\begin{array}{l}-0.001 \\
(0.008)\end{array}$ & & & & & & & \\
\hline CP Payments 94-99[€] & & & $\begin{array}{l}0.008^{*} \\
(0.005)\end{array}$ & & & & & & \\
\hline CP Payments 94-13 [€] & & & & $\begin{array}{r}0.003 \\
(0.003)\end{array}$ & & & & & \\
\hline GDP pc $2012[€ 000 \mathrm{~s}]$ & & & & & $\begin{array}{r}0.438^{* * *} * \\
(0.084)\end{array}$ & & & & \\
\hline Avg hourly wage $2012[€]$ & & & & & & $\begin{array}{c}0.799^{* * *} \\
\quad(0.167)\end{array}$ & & & \\
\hline Emplyment rate 2012 [\&] & & & & & & & $\begin{array}{r}0.708 \\
(0.444)\end{array}$ & & \\
\hline EU10 migrant stock ratio $2013 / 03$ & & & & & & & & $\begin{array}{r}0.335 \\
(0.217)\end{array}$ & \\
\hline EU 27 migrant stock ratio $2013 / 03$ & & & & & & & & & $\begin{array}{r}1.681 \\
(2.651)\end{array}$ \\
\hline Constant & $\begin{array}{r}47.20 * * * \\
(1.599)\end{array}$ & $\begin{array}{c}47.25^{* * *} \\
(1.833)\end{array}$ & $\begin{array}{c}45.53 * * * \\
(1.546)\end{array}$ & $\begin{array}{c}45.74 * * * \\
(1.821)\end{array}$ & $\begin{array}{c}33.93^{* * *} * \\
(2.723)\end{array}$ & $\begin{array}{c}30.69 * * * \\
(3.588)\end{array}$ & $\begin{array}{r}14.01 \\
(20.788)\end{array}$ & $\begin{array}{c}43.99^{* * * *} \\
(2.406)\end{array}$ & $\begin{array}{r}44.22 * * * \\
(4.753)\end{array}$ \\
\hline R-sqrd & 0.0003 & 0.0004 & 0.0889 & 0.0334 & 0.437 & 0.3953 & 0.0678 & 0.0638 & 0.0114 \\
\hline F-stat & 0.01 & 0.01 & $3.42^{*}$ & 1.21 & $27.17^{* * *}$ & $22.88^{* * *}$ & 2.54 & 2.38 & 0.4 \\
\hline $\mathrm{N}$ & 37 & 37 & 37 & 37 & 37 & 37 & 37 & 37 & 37 \\
\hline
\end{tabular}




\begin{tabular}{|c|c|c|c|c|c|c|c|}
\hline \multicolumn{8}{|c|}{ Table 3 Regression Results: Multivariate Analysis } \\
\hline CP Payments 07-13 [€] & $\begin{array}{r}(1) \\
0.010 \\
(0.007)\end{array}$ & $\begin{array}{r}(2) \\
0.010 \\
(0.007)\end{array}$ & $\begin{array}{r}(3) \\
0.011 \\
(0.009)\end{array}$ & $\begin{array}{r}(4) \\
0.012 \\
(0.010)\end{array}$ & (5) & (6) & (7) \\
\hline $\begin{array}{l}\text { CP Payments 00-06 }[€] \\
\text { CP Payments 94-99 }[€]\end{array}$ & & & & & & & \\
\hline CP Payments 94-13 [€] & & & & & $\begin{array}{r}0.002 \\
(0.003)\end{array}$ & $\begin{array}{l}0.005^{*} \\
(0.003)\end{array}$ & $\begin{array}{l}0.006^{* *} \\
(0.002)\end{array}$ \\
\hline GDP pc $2012[€ 000 \mathrm{~s}]$ & $\begin{array}{r}0.421^{* * *} \\
(0.066)\end{array}$ & $\begin{array}{r}0.414^{* * *} \\
(0.065)\end{array}$ & $\begin{array}{r}0.489^{* * *} \\
(0.081)\end{array}$ & $\begin{array}{r}0.485^{* * *} \\
(0.091)\end{array}$ & $\begin{array}{r}0.475^{* * *} \\
(0.081)\end{array}$ & $\begin{array}{r}0.466^{* * *} \\
(0.088)\end{array}$ & $\begin{array}{r}0.451^{* * *} \\
(0.086)\end{array}$ \\
\hline Avg hourly wage $2012[€]$ & & & & & & & \\
\hline Emplyment rate $2012[\&]$ & $\begin{array}{l}-0.027 \\
(0.282)\end{array}$ & $\begin{array}{r}0.041 \\
(0.270)\end{array}$ & $\begin{array}{r}0.287 \\
(0.345)\end{array}$ & $\begin{array}{r}0.126 \\
(0.384)\end{array}$ & $\begin{array}{r}0.196 \\
(0.339)\end{array}$ & $\begin{array}{r}0.153 \\
(0.370)\end{array}$ & $\begin{array}{r}0.213 \\
(0.362)\end{array}$ \\
\hline EU10 migrant stock ratio $2013 / 03$ & $\begin{array}{l}-0.148 \\
(0.191)\end{array}$ & & $\begin{array}{r}0.518^{* * *} \\
(0.151)\end{array}$ & & $\begin{array}{r}0.456^{* *} \\
(0.193)\end{array}$ & & \\
\hline EU 27 migrant stock ratio $2013 / 03$ & & $\begin{array}{l}-2.087 \\
(1.713)\end{array}$ & & $\begin{array}{l}3.635^{*} \\
(1.995)\end{array}$ & & $\begin{array}{r}1.961 \\
(2.261)\end{array}$ & \\
\hline England/Wales & $\begin{array}{r}-14.74^{* * *} \\
(3.307)\end{array}$ & $\begin{array}{r}-14.490^{* * *} \\
(2.491)\end{array}$ & & & & & \\
\hline Constant & $\begin{array}{r}49.162^{* * *} \\
(14.997) \\
\end{array}$ & $\begin{array}{r}48.185^{* * *} \\
\quad(13.320) \\
\end{array}$ & $\begin{array}{r}13.423 \\
(15.977) \\
\end{array}$ & $\begin{array}{r}19.583 \\
(17.620) \\
\end{array}$ & $\begin{array}{r}18.690 \\
(15.427) \\
\end{array}$ & $\begin{array}{r}20.739 \\
(16.502) \\
\end{array}$ & $\begin{array}{r}21.254 \\
(16.430) \\
\end{array}$ \\
\hline R-sqrd & 0.7629 & 0.7694 & 0.611 & 0.5178 & 0.5977 & 0.538 & 0.5271 \\
\hline F-stat & $19.95^{* * *}$ & $20.69^{* * *}$ & $12.57^{* * *}$ & $8.59^{* * *}$ & $11.89^{* * *}$ & 9.32 & 12.26 \\
\hline $\mathrm{N}$ & 37 & 37 & 37 & 37 & 37 & 37 & 37 \\
\hline
\end{tabular}


Figure 1: CP Payments 2007-13

EU Funds per capita 2007-2013

औै

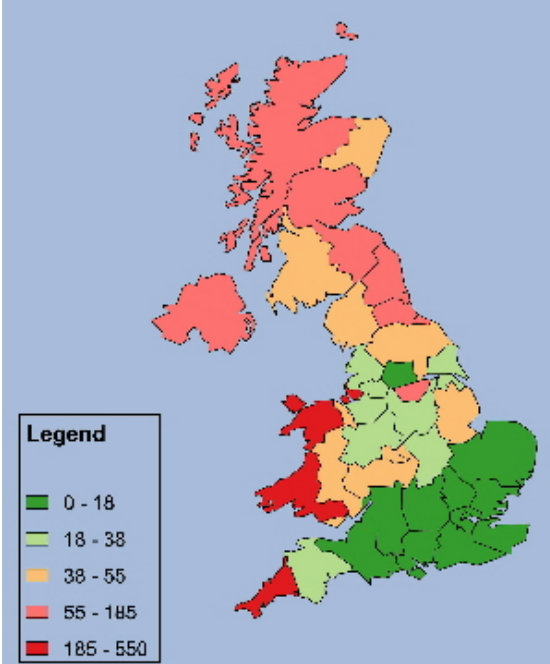

Figure 2: CP Payments 2000-06

EU Funds per capita 2000-2006

过

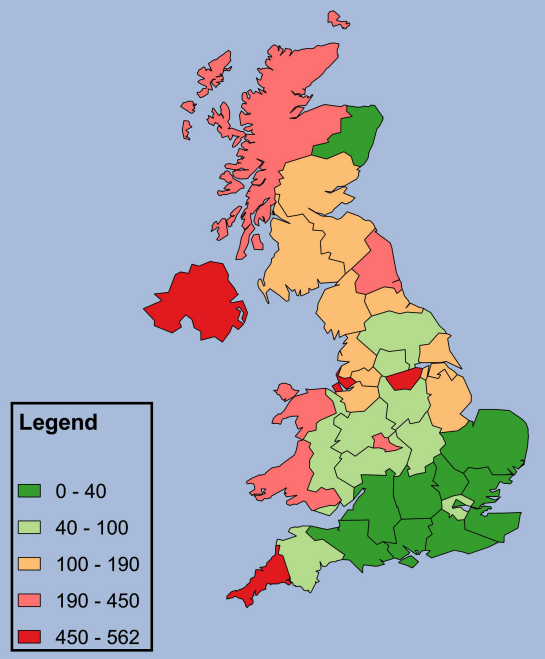


Figure 3: CP Payments 1994-99

EU Funds per capita 1994-1999

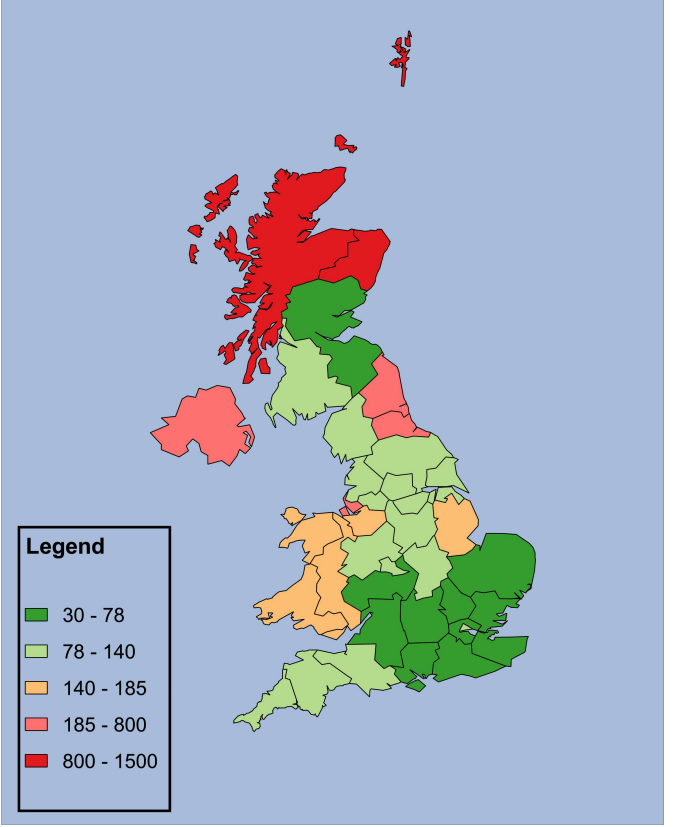


Figure 4: Remain Vote

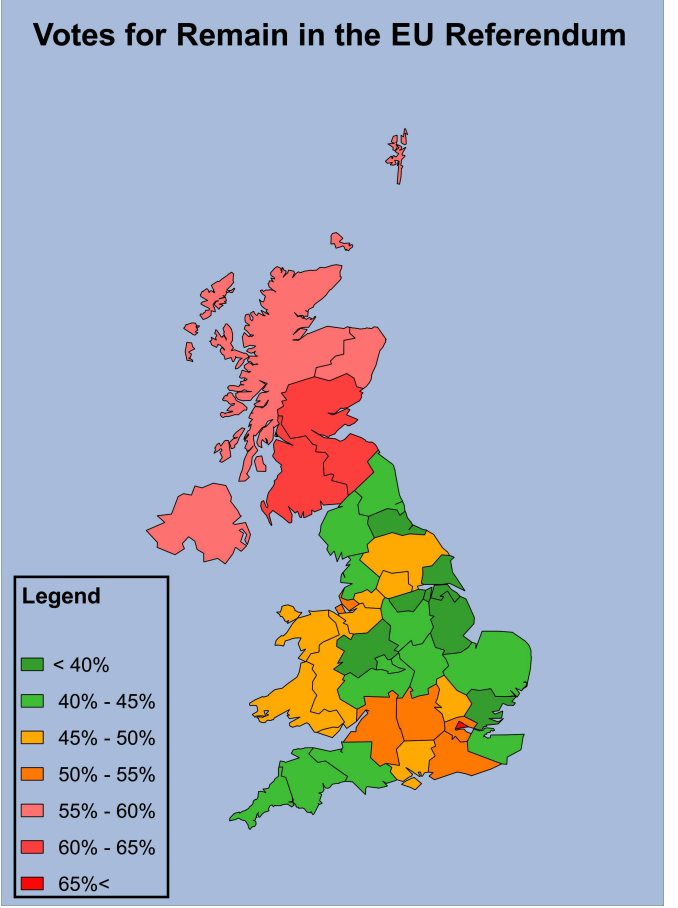

Figure 5: 
Figure 6: Immigration

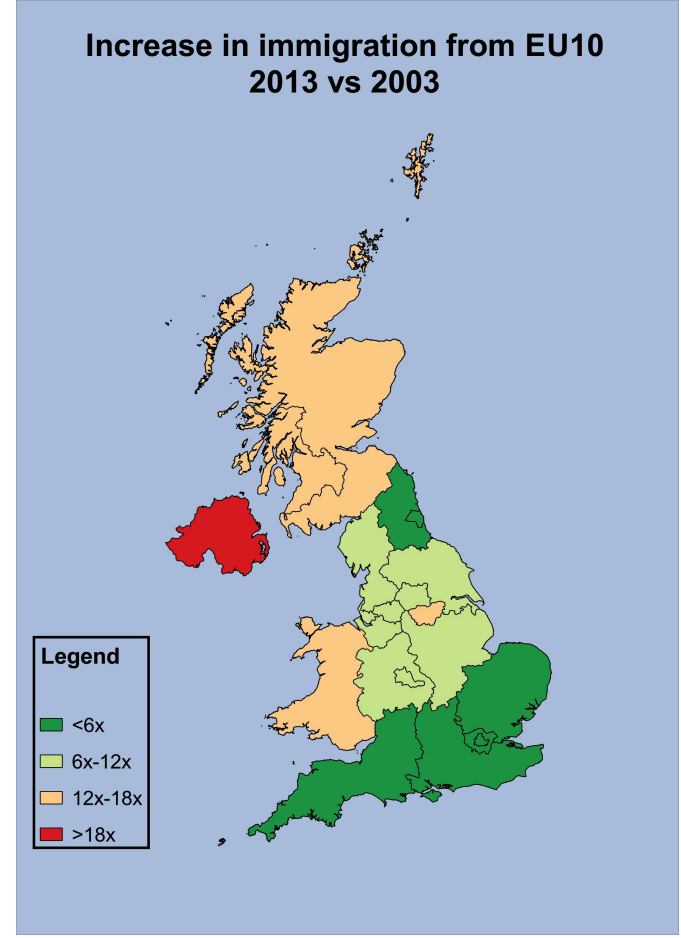

